\title{
Effect of seafloor depth on phytoplankton blooms in high-nitrate, low-chlorophyll (HNLC) regions
}

\author{
T. Tyrrell, ${ }^{1}$ A. Merico, ${ }^{1}$ J. J. Waniek, ${ }^{1,2}$ C. S. Wong, ${ }^{3}$ N. Metzl, ${ }^{4}$ and F. Whitney ${ }^{3}$ \\ Received 1 April 2005; revised 19 July 2005; accepted 26 August 2005; published 15 November 2005.
}

[1] We calculated correlations between seafloor depth and phytoplankton blooms in all three main high-nitrate, low-chlorophyll (HNLC) regions, but with a particular focus on the subarctic North Pacific area. It has long been known that the central parts of the east and west subarctic North Pacific are HNLC regions. The deep western basin of the Bering Sea is also HNLC, whereas the wide continental shelf of the eastern Bering Sea is not. We carried out a statistical comparison of spatial maps of (1) seafloor depth and (2) chlorophyll $a$ concentration from satellite data. This comparison reveals that shallow waters have, on average, higher peak chlorophyll $a$ concentrations (more intense phytoplankton blooms) than deep waters ( $\mathrm{p} \ll 0.01$ ). Possible artifacts of the satellite data are considered but it is concluded that the signal is genuine, in part because the same patterns are found in in situ data. There are several possible explanations for the observed correlation; the most probable, we suggest, is that iron diffusing out of the seafloor causes alleviation of iron limitation in shallow waters.

Citation: Tyrrell, T., A. Merico, J. J. Waniek, C. S. Wong, N. Metzl, and F. Whitney (2005), Effect of seafloor depth on phytoplankton blooms in high-nitrate, low-chlorophyll (HNLC) regions, J. Geophys. Res., 110, G02007, doi:10.1029/2005JG000041.

\section{Introduction}

1.1. High-Nitrate, Low-Chlorophyll Phenomenon and Mesoscale Iron Fertilization Experiments

[2] Macronutrients such as nitrate are either perennially or seasonally depleted in most surface oceans of the world. Three exceptions are the eastern equatorial Pacific Ocean, the subarctic North Pacific Ocean, and the Southern Ocean, together accounting for about $30 \%$ of global ocean surface area. Nitrate concentrations are high throughout the year in these regions, yet there is a surprising absence of phytoplankton blooms, leading to the term high-nitrate, lowchlorophyll (HNLC) regions. The cause of these anomalous areas has long been debated, with three hypotheses most actively considered: (1) a growth-limiting scarcity of the micronutrient iron [Martin, 1990a], (2) top-down grazing control [e.g., Frost, 1991; Fasham, 1995], and (3) low light levels [Mitchell and Holm-Hansen, 1991b]. The most parsimonious explanation would involve the same cause for all three HNLC regions, but the reality could of course be more complex. The low-light explanation has been put forward mainly for the Southern Ocean; mixed layer depths are rather shallow year round in the subarctic North Pacific (15-30 $\mathrm{m}$ in summer, maximum $\sim 120 \mathrm{~m}$ in winter) and in

\footnotetext{
${ }^{1}$ National Oceanography Centre Southampton, Southampton University, Southampton, UK.

${ }^{2}$ Now at Institut Für Ostseeforschung Warnemünde, Rostock, Germany.

${ }^{3}$ Institute of Ocean Sciences, Sidney, British Columbia, Canada.

${ }^{4}$ Laboratoire d'Océanographie et du Climati Expérimentations et Approches Numériques (LOCEAN)-IPSL/CNRS, Université Pierre et Marie Curie, Paris, France.
}

Copyright 2005 by the American Geophysical Union. 0148-0227/05/2005JG000041 the eastern equatorial Pacific (typically $25-40 \mathrm{~m}$ ), and the surface layers in these latter two areas should therefore be adequately illuminated.

[3] During the last decade the first of these hypotheses has been tested by multiple mesoscale iron fertilization experiments: two in the eastern equatorial Pacific [Martin et al., 1994; Coale et al., 1996], four in the Southern Ocean [Boyd et al., 2000; Gervais et al., 2002; Coale et al., 2004] and most recently two in the subarctic North Pacific (one on the western side closer to Japan [Tsuda et al., 2003], one on the eastern side in the Gulf of Alaska [Boyd et al., 2004]). (A fifth Southern Ocean iron enrichment experiment (EIFEX) was carried out in February 2004 and a second western subarctic Pacific experiment (SEEDS II) in July and August 2004, but their results have not yet been reported.) The results of all the published experiments have been synthesized by de Baar et al. [2005]. Dramatic proliferations of phytoplankton were seen in response to all the iron enrichments, together with strong drawdowns of nitrate and carbon. IronEx-1 was a partial exception in that the water mass was subducted beneath the surface several days after fertilization, bringing an end to the increase in chlorophyll [Martin et al., 1994]. Diatoms increased in number in response to the added iron and came to dominate the phytoplankton community by the ends of the experiments. In the SOFeX experiment, iron was added to two patches, a southern patch (in polar waters) high in both nitrate and silicate, and a northern patch (in subantarctic waters) high in nitrate but low in silicate: Diatoms came to dominate following the iron fertilization of the southern patch, but silicate limitation led to eventual co-dominance between diatoms and flagellated algae in the northern patch [Coale et al., 2004]. During all in situ fertilizations the small picophytoplankton $(<2 \mu \mathrm{m})$ which were numerically dominant 
prior to seeding underwent only a small increase in numbers as a result of the added iron, leading to the suggestion that the picophytoplankton are grazer controlled even if diatoms and some others are not [Price et al., 1994; Landry et al., 1995]. The eventually dominant diatoms, by weight, have been middle-sized or relatively large species such as Pseudo-nitzschia sp., Chaetoceros debilis or Fragilariopsis kerguelensis [de Baar et al., 2005]. From these experiments it seems likely that parts of the phytoplankton community are top-down controlled by grazers, and hence unable to increase in number in response to the added iron, whereas other parts of the community (particularly large diatoms) are able to proliferate when their bottom-up limitation is removed, even when simultaneously being heavily grazed [Strom et al., 2001; Banse, 2002].

[4] From a biogeochemical perspective it may make little difference if part of the community is kept under control by grazers. Even if only one species is free to proliferate in response to additions of the most limiting nutrient, then total community export will still end up being limited by the supply rate of that nutrient. The explanation of HNLC areas may thus be twofold [Cullen et al., 1992; Price et al., 1994; de Baar et al., 2005]: (1) that the proliferation of picophytoplankton is capped by microzooplankton grazing, and (2) that the proliferation of large diatoms and other phytoplankton is held back by lack of iron. Both classes of phytoplankton, but for different reasons, are prevented from consuming the excess nitrate.

[5] In recent years, increasing attention has been paid to the higher dissolved iron concentrations in shallow waters, perhaps deriving from the sediments (see section 4.3 for further discussion). This has led to the suggestion that "iron is not likely to be biolimiting over a continental shelf" [Bucciarelli et al., 2001]. If we ignore occasional exceptions to this generalization (section 4.3), and if HNLC is caused by iron scarcity, then this statement leads to the expectation that HNLC conditions should not occur in shallow waters, because iron limitation is alleviated.

\subsection{Island Effects}

[6] When considered across the globe, phytoplankton primary production [Muller-Karger et al., 2005] and organic carbon burial [Berner, 1992] tend to be disproportionately high in shallow water compared to deep water. In the Southern Ocean, in particular, it has been recognized for decades that elevated levels of chlorophyll and phytoplankton production are occasionally found close to islands and over continental shelves [e.g., de Baar and de Jong, 2001; Watson, 2001; Banse, 1996], in contrast to generally lower levels in deep waters. Higher chlorophyll concentrations have also been detected between the Galapagos Islands, compared to the values in the surrounding eastern equatorial Pacific [Martin et al., 1994; Chavez et al., 1991]; some instances of higher values near to the coast were also noted for the North Pacific by Banse and English [1999] in their wide-ranging review.

[7] Banse and English [1999] made use of data from the Coastal Zone Color Scanner (CZCS) satellite sensor, which ceased operation in 1986. Since September 1997 improved ocean color data have been available from a new range of sensors such as SeaWiFS, MODIS and MERIS. Modern digital data sets of seafloor bathymetry have been produced by the amalgamation of: (1) seafloor data determined along cruise tracks by depth soundings, and (2) estimates of seafloor depth from satellite altimeter data [Smith and Sandwell, 1997]. The combination of high-resolution, global-coverage data sets for both seafloor topography and for sea-surface chlorophyll $a$ allows comparison of the two to look for correlations. Moore and Abbott [2000] carried out such a cross-comparison in the Southern Ocean from Antarctica north to $30^{\circ} \mathrm{S}$. They found (in agreement with an earlier CZCS study by Comiso et al. [1993]) that, on average, surface chlorophyll concentrations were higher in areas of shallow water depth $(<500 \mathrm{~m})$ than in areas where the seafloor was deeper, and that this correlation between bathymetry and chlorophyll was stronger than that between chlorophyll and any of the other variables that they examined. Their choice of latitudes (northern limit of $30^{\circ} \mathrm{S}$ ), however, allows inclusion of waters outside the HNLC region. Nutrient data sets, such as the World Ocean Atlas [Levitus et al., 1993] and the World Ocean Circulation Experiment (WOCE), show that the boundary between nitrate-poor and nitrate-rich waters, which varies with longitude and season, is in some places as far south as $40^{\circ} \mathrm{S}$ (see also auxiliary material supplfig $02^{1}$ ). Here we restrict our area of investigation to include only latitudes containing HNLC waters.

[8] In this study we carried out a systematic comparison of bathymetric and chlorophyll $a$ data sets. This analysis was carried out in all three HNLC areas but focused in particular on the North Pacific area because: (1) a systematic analysis has not previously been attempted there, and (2) there has been intense in situ sampling of chlorophyll and nutrients during recent years in the subarctic North Pacific and adjacent seas, including about 4000 stations on board the commercial cargo carrier M/V Skaugran during numerous transects across the North Pacific between January 1995 and January 2001 [Wong et al., 2002]. These in situ data are useful because they enable validation of the results of the satellite analyses. In addition, whereas there is relatively little shelf area in the eastern equatorial Pacific, the great extent of the eastern Bering Sea shelf (large number of shallow water pixels in the satellite images) considerably improves the quality of the statistical comparison.

\section{Methods}

[9] Our analysis of satellite-derived chlorophyll $a$ concentrations used data from the Sea-viewing Wide Field-ofView (SeaWiFS) sensor. Chlorophyll $a$ concentrations were estimated from remote-sensed radiances using the OC4v4 algorithm [O'Reilly et al., 2000], developed for "Case 1" waters low in colored dissolved organic matter and suspended particulate material. The chlorophyll $a$ maps shown in this paper are annual composite images generated from many overpasses of the satellite; they are calculated by NASA using a weighted average of all valid values during the composite period. Annual composites are used for the figures, whereas monthly composites are used for the statistical calculations, for reasons outlined below. Annual composite images as well as monthly chlorophyll- $a$ values

${ }^{1}$ Auxiliary material is available at $\mathrm{ftp} / / \mathrm{ftp}$.agu.org/apend/jg/ 2005JG000041. 
used in the statistical calculations were taken from SeaWiFS Global Area Coverage (GAC) level 3 Standard Mapped Image data from the NASA-GSFC DAAC: http://oceancolor. gsfc.nasa.gov/cgi/level3.pl.

[10] One characteristic of HNLC waters is a low and rather constant chlorophyll concentration through the year (hence the LC in HNLC), as exemplified by data collected over many years at Ocean Weather Station Papa in the subarctic North Pacific where chlorophyll concentrations are almost always $<1 \mathrm{mg}$ chl- $a \mathrm{~m}^{-3}$. This is in contrast to most temperate latitudes, which typically experience intense spring blooms (although these could be missed by the satellite in any one year because of cloud cover) but lower values through the rest of the year (occasionally a smaller fall bloom is also observed). Because of our interest in discriminating between HNLC areas (no blooms) and nonHNLC areas (blooms), we worked with peak rather than average chlorophyll-a concentrations. These were calculated as the maximum out of 58 (September 1997 through to June 2002) monthly composite (i.e., average) values for each $0.5^{\circ} \times 0.5^{\circ}$ grid cell.

[11] We worked with monthly rather than annual average chlorophyll $a$ values in order to obtain an estimate of peak bloom concentrations. However, phytoplankton blooms persist typically for only a week or so and it is therefore likely that our peak chlorophyll $a$ concentrations are underestimates. We would expect analyses using weekly or daily chlorophyll $a$ values to yield higher peak chlorophyll $a$ concentrations. Maximum monthly chlorophyll $a$ values greater than $30 \mathrm{mg} \mathrm{m}^{-3}$ were omitted from the analysis to exclude undue influence of outliers.

[12] Seafloor depth for each $0.5^{\circ} \times 0.5^{\circ}$ grid cell was calculated as the shallowest depth in that cell, according to the GTOPO30 bathymetry data set [Smith and Sandwell, 1997]. This data set combines information from depth soundings taken from ships together with anomalies in the marine gravity field as determined from satellites; the latter are caused primarily by variations in height of the seafloor and are derived from satellite altimeter measurements of the sea surface [Smith and Sandwell, 1997].

\section{Results}

[13] Chlorophyll $a$ and bathymetry maps for several different areas are presented side-by-side to allow comparison (Figure 1 and auxiliary material supplfig01). Visual inspection shows that most high phytoplankton concentrations (yellows and reds) occur in shallow water. It also shows that the connection between bathymetry and chlorophyll-a concentrations is not absolute. In particular it can be seen that some deep waters close to continental shelves contain high rather than low phytoplankton concentrations (for instance along the northern edge of the western basin of the Bering Sea, or east of the Kamchatka peninsula, particularly in 2002). This may be a result of eddies advecting off shelves, taking iron-rich coastal water with them out into the adjacent open ocean [Johnson et al., 2005; Whitney and Robert, 2002]; chlorophyll concentrations are high in such eddies [Crawford et al., 2005] and nutrient drawdown continues until either nitrate or silicate [Peterson et al., 2005; Whitney et al., 2005] become biolimiting. In other locations, where prevailing ocean currents sweep water rapidly across shallow topography, high chlorophyll $a$ concentrations occur in large part downstream of islands and submerged banks. This is seen particularly in the Southern Ocean (bottom half of Figure 1). The Antarctic Circumpolar Current (ACC) sweeps around Antarctica in a predominantly eastward direction, but its path is deflected northward at South Georgia [Korb et al., 2004] and Crozet [Pollard et al., 2002], which lie in its path, and flows eastward north of Kerguelen Island [Blain et al., 2001]. High chlorophyll $a$ plumes are seen downstream of all these islands, and of the Antarctic peninsula (Figure 1).

[14] We carried out a systematic analysis to examine whether the visually apparent correlation is supported statistically; that is to say, we checked whether the pattern seen by eye, of higher chlorophyll $a$ concentrations in shelf waters compared to deep waters, is borne out by statistical analysis of the data. The bar charts in the right-hand column of Figure 1 were obtained by binning chlorophyll $a$ concentrations (maximum monthly values between September 1997 and June 2002) according to seafloor depth. The height of the first bar therefore represents the average of the maximum chlorophyll $a$ concentrations in all grid cells containing seafloor shallower than $100 \mathrm{~m}$. Bars are only shown for depth intervals where $\mathrm{N}>10$, and for this reason there are only a few bars for shallow ocean in the equatorial Pacific (where the Galapagos Islands are surrounded by only a narrow continental shelf).

[15] The suggestion that peak chlorophyll $a$ concentrations are higher in shallow water is supported by the statistical analysis (Table 1). Average peak concentrations were higher in shallow water in every HNLC area that we examined, and the difference was statistically significant in each case (Table 1). A similar on-shelf/off-shelf distinction was also found in non-HNLC waters, for instance when we

Figure 1. Comparison of bathymetry and chlorophyll $a$ in HNLC systems. Each row corresponds to a different HNLC system (rows numbered from top to bottom): (1) Bering Sea, (2) subarctic North Pacific, (3) eastern Equatorial Pacific, (4) Southern Ocean (Indian Ocean sector) encompassing the islands of Kerguelen and Crozet, (5) Southern Ocean (Atlantic Sector) encompassing South Georgia, the South Orkney and the South Sandwich Islands, and (6) Southern Ocean around the Antarctic Peninsula. Column 1 shows seafloor bathymetry from the ETOPO2 $\left(2^{\prime} \times 2^{\prime}\right)$ data set plotted using the OCEANMAP package. The second shows corresponding chlorophyll $a$ maps (SeaWiFS, OC4v4 algorithm, 2001 annual composite). The $200-\mathrm{m}$ - and 500-m-depth contours are overlaid in white. The third column shows a bar chart of average maximum monthly chlorophyll $a$ for each seafloor depth bin (see section 2 of main text). Standard deviations are shown in red. The color scale for the bathymetric maps is chosen to emphasize the distinction between shelves and deeper waters. The color scale for the chlorophyll $a$ maps (annual composites for 2001 shown here, for 1998-2001 shown in auxiliary material supplfig01) is the standard NASA color scale. Pixels with no valid chlorophyll-a values during 2001 (for instance because of ice or cloud throughout) are colored black, as is land. 

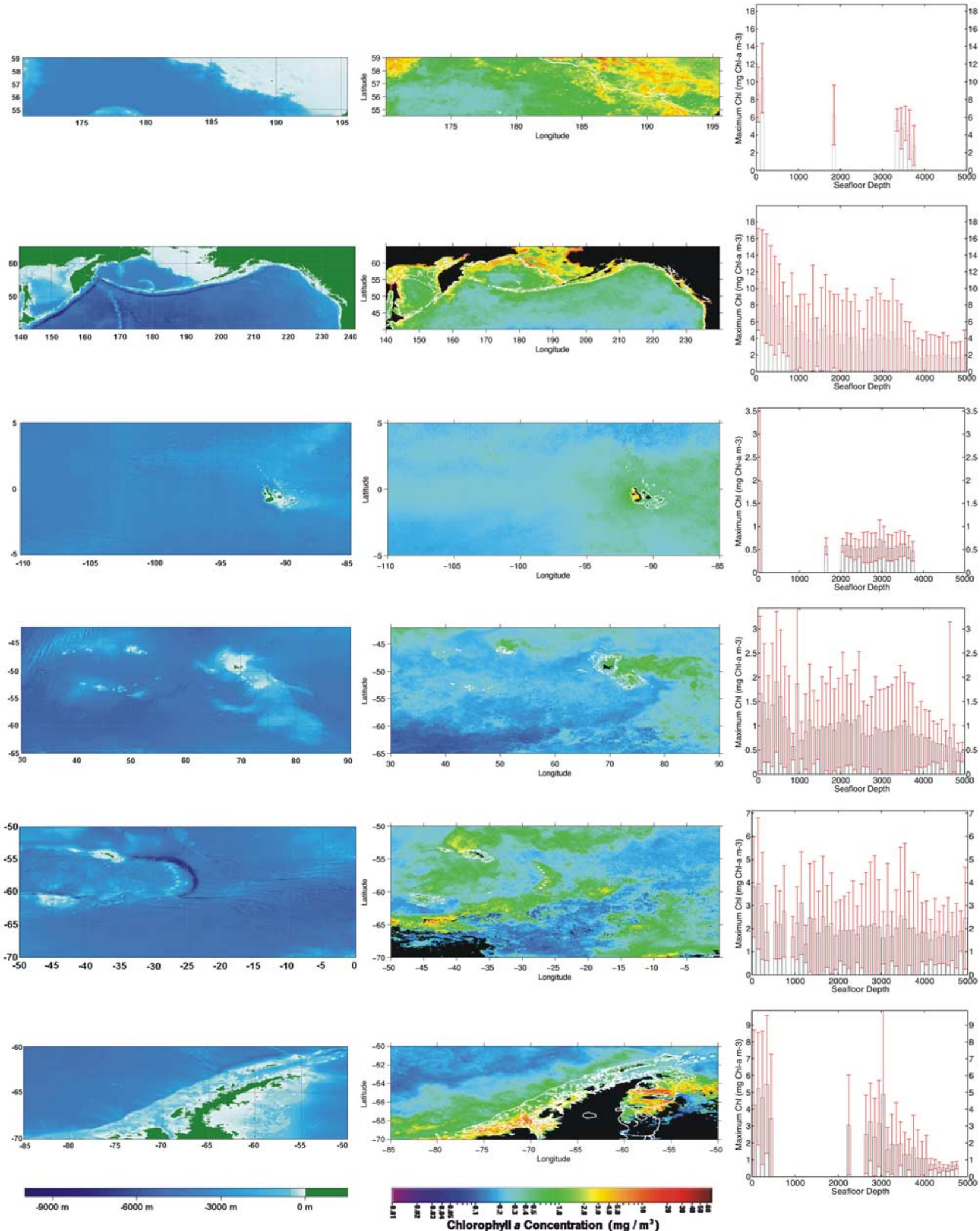

$.9000 \mathrm{~m}$

$6000 \mathrm{~m}$

$3000 \mathrm{~m}$

Chlorophyll a Concentration $\left(\mathrm{mg} / \mathrm{m}^{3}\right.$

Figure 1 
Table 1. Analysis of Influence of Seafloor Depth on Maximum Chlorophyll $a$ Concentration ([chl- $a])^{\mathrm{a}}$

\begin{tabular}{|c|c|c|c|c|c|c|c|c|c|}
\hline \multirow[b]{2}{*}{ HNLC Area } & \multirow{2}{*}{$\begin{array}{c}\text { Coordinates } \\
\text { (Longitude, Latitude) }\end{array}$} & \multicolumn{2}{|c|}{ Chl- $a$} & \multicolumn{2}{|r|}{$\sigma$} & \multicolumn{2}{|c|}{$\mathrm{N}$} & \multirow{2}{*}{$\begin{array}{l}\text { Chl- } a_{(\leq 200 \mathrm{~m})} \\
\text { Chl- } a_{(\geq 2000 \mathrm{~m})}\end{array}$} & \multirow[b]{2}{*}{$\mathrm{P}$} \\
\hline & & $(\leq 200 \mathrm{~m})$ & $(\geq 2000 \mathrm{~m})$ & $(\leq 200 \mathrm{~m})$ & $(\geq 2000 \mathrm{~m})$ & $(\leq 200 \mathrm{~m})$ & $(\geq 2000 \mathrm{~m})$ & & \\
\hline Subarctic North Pacific & $\left(140^{\circ} \mathrm{E}-120^{\circ} \mathrm{W}, 40^{\circ} \mathrm{N}-65^{\circ} \mathrm{N}\right)$ & 11.0 & 2.3 & 6.1 & 3.3 & 1905 & 4993 & 4.7 & $\gg 99 \%$ \\
\hline Bering Sea & $\left(170^{\circ} \mathrm{E}-164.5^{\circ} \mathrm{W}, 54.5^{\circ} \mathrm{N}-59^{\circ} \mathrm{N}\right)$ & 8.9 & 4.1 & 3.3 & 2.7 & 118 & 261 & 2.2 & $\gg 99$ \\
\hline Equatorial Pacific & $\left(110^{\circ} \mathrm{W}-85^{\circ} \mathrm{W}, 5^{\circ} \mathrm{S}-5^{\circ} \mathrm{N}\right)$ & 1.8 & 0.6 & 1.9 & 0.3 & 19 & 885 & 3.1 & $99 \%$ \\
\hline \multicolumn{10}{|l|}{ Southern Ocean } \\
\hline Crozet and Kerguelen & $\left(30^{\circ} \mathrm{E}-90^{\circ} \mathrm{E}, 65^{\circ} \mathrm{S}-42^{\circ} \mathrm{S}\right)$ & 1.6 & 0.8 & 1.5 & 0.9 & 158 & 4669 & 2.1 & $\gg 99 \%$ \\
\hline $\begin{array}{l}\text { South Georgia and } \\
\text { South Sandwich }\end{array}$ & $\left(50^{\circ} \mathrm{W}-0^{\circ} \mathrm{W}, 70^{\circ} \mathrm{S}-50^{\circ} \mathrm{S}\right)$ & 3.8 & 1.9 & 2.3 & 1.8 & 99 & 3232 & 2.0 & 4 \\
\hline Antarctic Peninsula & $\left(100^{\circ} \mathrm{W}-30^{\circ} \mathrm{W}, 72^{\circ} \mathrm{S}-60^{\circ} \mathrm{S}\right)$ & 4.5 & 1.5 & 4.3 & 1.9 & 263 & 597 & 3.0 & $\gg 99 \%$ \\
\hline
\end{tabular}

${ }^{\mathrm{a}}$ Seafloor depth (sz) and chlorophyll $a$ concentration for each $0.5^{\circ} \times 0.5^{\circ}$ grid cell are calculated as described in section 2 . Columns are ocean area, coordinates of box analyzed, average maximum monthly [chl-a] in all the grid cells where sz $\leq 200 \mathrm{~m}$ (shelf), average [chl- $a$ ] in all the grid cells where sz $\geq$ $2000 \mathrm{~m}$ (deep), standard deviation of [chl- $a$ ] values where sz $\leq 200 \mathrm{~m}$ (note that this is the standard deviation of the population, not of the mean), standard deviation of [chl- $a$ ] values where $\mathrm{sz} \geq 2000 \mathrm{~m}$, number of [chl- $a$ ] values where $\mathrm{sz} \leq 200 \mathrm{~m}$ (sample size), number of [chl- $a$ ] values where $\mathrm{sz} \geq 2000 \mathrm{~m}$, ratio of maximum $[\mathrm{chl}-a]$ value for shelf waters to maximum $[\mathrm{chl}-a]$ value for deep waters, and probability of a genuine difference between the two means (shelf and deep [chl-a]'s), using a Student's t-test in which the two variances are not assumed identical [Press et al., 1991].

compared chlorophyll $a$ concentrations over the Grand Banks to those in adjacent deeper waters (results of analysis not shown). In these cases, however, the difference can be understood as the result of intensive remineralization of macronutrients in the shallow sediments and their subsequent resupply to the surface waters. Because macronutrients are always present in excess in HNLC waters, the higher chlorophyll $a$ concentrations in adjacent shallow waters cannot be due to supply of additional macronutrients.

[16] Our results are in agreement with previous observations of high satellite chlorophyll $a$ concentrations around and downstream of the Galapagos [Palacios, 2002], South Georgia [Korb et al., 2004], Kerguelen [Blain et al., 2001] and Crozet Islands [Pollard et al., 2002]. A study of levels of phytoplankton chlorophyll along the Polar Front in the Southern Ocean found highest levels where it impinges on relatively shallow seafloor [Moore and Abbott, 2002]. An association between phytoplankton blooms and shallow waters/continental masses was previously suggested for the Southern Ocean, from CZCS data by Sullivan et al. [1993] and, from single years of SeaWiFS data, by Moore and Abbott [2000] and by Watson [2001]. In 4 years (19982001) of SeaWiFS imagery (Figure 1 and auxiliary material supplfig01) we found that blooms are also seen around and downstream of other islands in the Southern Ocean, such as Marion/Prince Edward and the South Sandwich Islands. These features repeat in all or most years in SeaWiFS data (auxiliary material supplfig01).

[17] If our hypothesis is correct (blooms in shallow waters, lack of blooms in deep waters), then the effects should also be manifest in nutrient data. The phytoplankton blooms in shallow waters would take up nutrients and, assuming the blooms are accompanied by export, lead to seasonal nutrient depletion. We took advantage of intense sampling during recent years in the subarctic North Pacific and adjacent seas. Nitrate data were collated from several areas within and adjacent to the HNLC subarctic North Pacific. These data show that low summer nitrate concentrations are also related to bathymetry (Figure 2) and that rates of nitrate drawdown are more rapid over shelves than over deep water (Table 2).

\section{Discussion}

\subsection{Limitations to Satellite Data Over Shelves}

[18] The OC4v4 algorithm is designed for "Case 1" waters, that is to say waters whose optical properties are dominated by phytoplankton and derivative products. Many coastal waters, on the other hand, are "Case 2"; their optical properties are affected by the presence of colored dissolved organic matter (CDOM) and suspended particulate material (SPM). It is therefore necessary to consider the extent to which detected on-shelf/off-shelf differences in [chl- $a$ ] could be due to artifacts associated with using OC4v4 in Case 2 waters for which it was not designed. The accuracy of OC4v4 is likely to be low in areas of high CDOM (for example where the absorption of light by CDOM is greater than about $0.1 \mathrm{~m}^{-1}$ at $380 \mathrm{~nm}$ ) or high SPM (for example where the concentration is greater than about $\left.0.5 \mathrm{~g} \mathrm{~m}^{-3}\right)$ [Mueller et al., 2002]. SeaWiFS OC4v4 chlorophyll a values should therefore be treated with caution within estuaries and near river mouths. Comparisons of SeaWiFS OC4v4 versus in situ chlorophyll $a$ measurements in such areas [Gohin et al., 2002; Richardson et al., 2004; Darecki and Stramski, 2004] show large statistical errors, for instance root-mean square differences between algorithm and in situ of $>200 \%$ [Darecki and Stramski, 2004]. Away from river mouths, the prediction of in situ chlorophyll $a$ by

Figure 2. Seasonal chlorophyll and nitrate concentrations in the subarctic North Pacific and adjacent waters (surface layer). (a, b) Data collected over 25 years $(1970-1995)$ at the Ocean Weather Station Papa (OWSP) site $\left(50^{\circ} \mathrm{N}, 145^{\circ} \mathrm{W}\right)$ in the eastern side of the subarctic North Pacific. The small number of high chlorophyll $a$ and low nitrate values could be due to occasional dust events [Boyd et al., 1998] or advection of coastal-derived eddies across the site [Johnson et al., 2005]; $(\mathrm{c}-\mathrm{f})$ data from the western side of the subarctic North Pacific $\left(160^{\circ} \mathrm{E}-180^{\circ} \mathrm{E}, 45^{\circ} \mathrm{N}-50^{\circ} \mathrm{N}\right)$ and from the western side of the Bering Sea $\left(175^{\circ} \mathrm{E}-175^{\circ} \mathrm{W}, 53^{\circ} \mathrm{N}-57^{\circ} \mathrm{N}\right)$, collected on board the commercial cargo carrier M/V Skaugran between January 1995 and January 2001 [Wong et al., 2002]; (g, h) data from the southeastern Bering Sea (middle shelf), assembled [Merico et al., 2005] from cruises of the T/V Oshoro Maru and from the World Ocean Database; (i, j) data from the shelf south of Alaska $\left(\sim 154^{\circ} \mathrm{W}-144^{\circ} \mathrm{W}, 58^{\circ} \mathrm{N}-61^{\circ} \mathrm{N}\right)$ from the World Ocean Database; (k, l) data from the CYPRIS sampling station $\left(4^{\circ} 50^{\prime} \mathrm{W}, 54^{\circ} 05^{\prime} \mathrm{N}\right)$, Irish Sea, for comparison. 
OC4v4 is much more accurate; a recent study in Case 1 coastal waters of the northeast New Zealand shelf calculated a root-mean square difference between algorithm and in situ of only 8\% [Pinkerton et al., 2005]. The possibility of Case 2 overestimations needs to be kept in mind when interpreting SeaWiFS chlorophyll data, and may account for some of the trends that we observe.
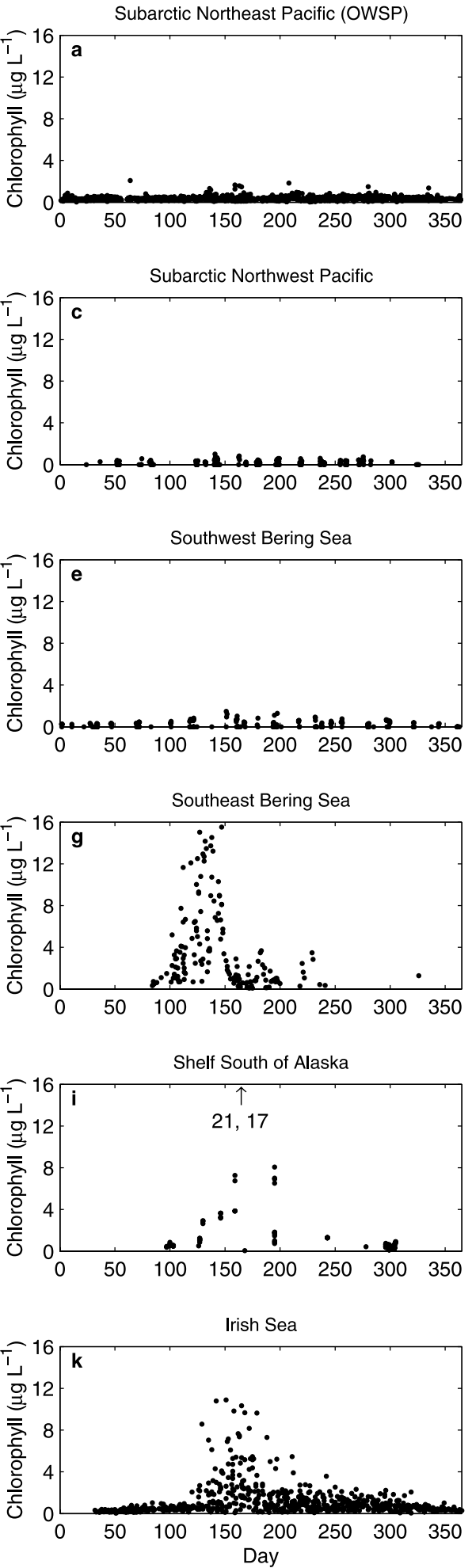

[19] Although ocean color estimates are accurate when averaged across the globe (mean ratio of SeaWiFS OC4v4 chl- $a$ to in situ chl- $a$ of 1.0056 [Eplee et al., 2001]), there is evidence that they are not so accurate in particular regions [Claustre and Maritorena, 2003]. In particular, several studies have found that satellite algorithms tend to underestimate high (peak) chlorophyll a concentrations
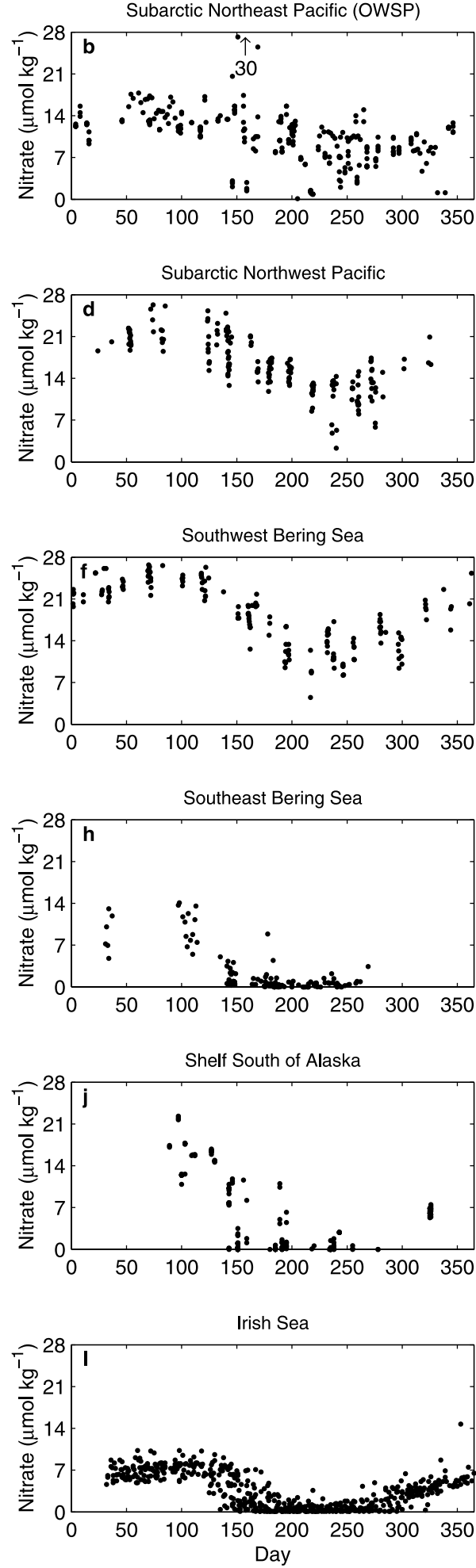

Figure 2 
Table 2. Seasonal Nitrate Characteristics ${ }^{\mathrm{a}}$

\begin{tabular}{|c|c|c|c|c|c|c|c|}
\hline Area & Shallow/Deep & $\begin{array}{l}\text { Spring } \\
\text { Blooms } \\
\end{array}$ & $\begin{array}{c}\text { Winter } \\
{\left[\mathrm{NO}_{3}\right]} \\
\mu \mathrm{mol} \mathrm{kg}^{-1} \\
\end{array}$ & $\begin{array}{l}\text { Summer } \\
{\left[\mathrm{NO}_{3}\right]} \\
\mu \mathrm{mol} \mathrm{kg} \\
\end{array}$ & $\begin{array}{c}\Delta[\mathrm{NO} 3] \\
\text { Winter-Summer, } \\
\mu \mathrm{mol} \mathrm{kg} \\
\end{array}$ & $\begin{array}{c}\text { Average } \\
\text { Rate of } \\
\text { [NO3] Decline, } \\
\mu \mathrm{mol} \mathrm{NO} \mathrm{Ng}_{3}^{-1} \mathrm{~d}^{-1}\end{array}$ & Reference \\
\hline \multicolumn{8}{|c|}{ Subarctic North Pacific } \\
\hline $\begin{array}{l}\text { OWS Papa (Station 'P') } \\
\left(49^{\circ} \mathrm{N}-51^{\circ} \mathrm{N},\right. \\
\left.146^{\circ} \mathrm{W}-144^{\circ} \mathrm{W}\right)\end{array}$ & deep & no & $14^{\mathrm{b}}$ & $8^{\mathrm{b}}$ & 6 & 0.03 & $\begin{array}{l}\text { Whitney and Freeland [1999]; } \\
\text { Wong et al. [2002]; Figure } 2 \mathrm{~b}\end{array}$ \\
\hline $\begin{array}{l}\text { Western side } \\
\qquad\left(45^{\circ} \mathrm{N}-50^{\circ} \mathrm{N},\right. \\
\left.\quad 160^{\circ} \mathrm{E}-180^{\circ} \mathrm{E}\right)\end{array}$ & deep & no & 22 & 12 & 10 & 0.06 & Wong et al. [2002]; Figure 2d \\
\hline \multicolumn{8}{|c|}{ Bering Sea } \\
\hline $\begin{array}{l}\text { Western (deep basin) } \\
\quad\left(53^{\circ} \mathrm{N}-57^{\circ} \mathrm{N},\right. \\
\left.175^{\circ} \mathrm{E}-175^{\circ} \mathrm{W}\right)\end{array}$ & deep & no & $24(22-27)$ & $12(8-15)$ & 12 & 0.07 & Wong et al. [2002]; Figure $2 \mathrm{f}$ \\
\hline $\begin{array}{l}\text { Eastern (middle shelf) } \\
\left(56^{\circ} \mathrm{N}-58^{\circ} \mathrm{N}\right. \\
\left.170^{\circ} \mathrm{W}-160^{\circ} \mathrm{W}\right)\end{array}$ & shallow & yes & $12(5-15)$ & $1(0-1)$ & 11 & 0.4 & $\begin{array}{l}\text { Merico et al. [2005]; } \\
\text { Whitledge and Luchin [1999]; } \\
\text { Figure } 2 \mathrm{~h}\end{array}$ \\
\hline \multicolumn{8}{|c|}{ Edges of Subarctic North Pacific } \\
\hline Shelf south of Alaska & shallow & yes & $10-15$ & $<1$ & $10-15$ & $\mathrm{n} / \mathrm{a}$ & $\begin{array}{l}\text { Childers et al. [2005]; } \\
\text { Whitney and Welch [2002]; } \\
\text { Figure } 2 \mathrm{j}\end{array}$ \\
\hline $\begin{array}{l}\text { British Columbia shelf } \\
\text { (El Niño years: } \\
\text { 1997-1998) }\end{array}$ & shallow & yes & $10-15$ & $<1$ & $10-15$ & $\mathrm{n} / \mathrm{a}$ & Whitney and Welch [2002] \\
\hline $\begin{array}{l}\text { British Columbia shelf } \\
\text { (La Niña year: 1999) }\end{array}$ & shallow & yes & $10-15$ & $0-15$ & variable & $\mathrm{n} / \mathrm{a}$ & Whitney and Welch [2002] \\
\hline Irish Sea (for comparison) & shallow & yes & $8^{\mathrm{c}}$ & $<1$ & 7 & 0.2 & Figure 21 \\
\hline
\end{tabular}

${ }^{a}$ Data show rate and amount of nitrate removal in the different areas. The penultimate column gives an indication of the approximate rapidity with which nitrate is consumed during the spring/early summer. This number cannot be calculated accurately from multiyear data sets, because of interannual differences in spring bloom timings at the same location (for instance, calculations using data from individual years suggest an average nitrate uptake rate of about $0.75 \mu \mathrm{mol} \mathrm{NO} \mathrm{Ng}_{3}^{-1} \mathrm{~d}^{-1}$ during spring blooms in the eastern Bering Sea [Whitledge et al., 1986], about twice the value calculated here from multiannual data). The values in this column should therefore be considered only in relative terms. The important point here is that nitrate utilization proceeds more rapidly (and until nitrate is exhausted) in shallow waters. At first glance, the shelf off British Columbia appears to be an exception to this rule. However, high summer nitrate levels there are a consequence of coastal upwelling during summer; widespread nitrate depletion was observed along the shelf when this upwelling was suppressed during the 1997-1998 El Niño [Whitney and Welch, 2002]. Here n/a means number not available.

${ }^{\mathrm{b}}$ This is the approximate average 1969-1997, during which time there has been a long-term trend toward lower nitrate concentrations in more recent years: summer and winter averages are approximately 9 and $15 \mu \mathrm{mol} \mathrm{kg}{ }^{-1}$ during $1969-1981$ and approximately 7 and $13 \mu \mathrm{mol} \mathrm{kg}^{-1}$ during $1992-1997$ [Whitney and Freeland, 1999].

${ }^{c}$ This is the approximate average 1960-2003, during which time there has been a long-term trend toward higher nitrate concentrations in more recent years: winter average is approximately $6 \mu \mathrm{mol} \mathrm{kg} \mathrm{kg}^{-1}$ during the $1960 \mathrm{~s}$ and approximately $10 \mu \mathrm{mol} \mathrm{kg} \mathrm{m}^{-1}$ during the $1990 \mathrm{~s}$; summer average is always $0-1 \mu$ mol $\mathrm{kg}^{-1}$ (K. Kennington et al., Biogeochemical signature of recent climate variability in the Irish Sea, submitted to Limnology and Oceanography, 2004).

$\left(>1 \mathrm{mg} \mathrm{chl}-a \mathrm{~m}^{-3}\right)$ by a factor of 2 or more in the Southern Ocean [Mitchell and Holm-Hansen, 1991a; Sullivan et al., 1993; Korb et al., 2004]. The lower on-shelf/off-shelf chlorophyll $a$ ratios calculated here in the Southern Ocean (Table 1, column 9), compared to elsewhere, are probably related to this underestimation of the highest phytoplankton concentrations.

\subsection{Multiple Lines of Evidence Show That HNLC is Alleviated Over Shelves}

[20] CDOM and SPM are not, however, responsible for a large part of the observed correlation. There is a significant difference both where the shelf is relatively narrow, and also over the extensive continental shelf of the eastern Bering Sea, some parts of which are more than a hundred kilometers from any land. The on-shelf/off-shelf difference in chlorophyll $a$ concentrations is also apparent in seasonal cycles of $[$ chl- $a$ ] which have been compiled from data collected from ships (left-hand side of Figure 2). Occasional very high phytoplankton concentrations have historically been observed at many locations around the world where shallow seafloor intrudes into HNLC waters (Table 3). Where the spatial patterns of both satellite data and in-situ data can be compared, there seems to be broad agreement (auxiliary material supplfig02).

[21] A second characteristic of HNLC waters is the yearround persistence of high concentrations of macronutrients (hence the HN in HNLC), even in spring and summer. Spring blooms in temperate non-HNLC waters such as the northern North Atlantic and the North Sea deplete nitrate and other macronutrients, giving rise to nitrate exhaustion (low concentrations, generally $<1 \mu \mathrm{mol} \mathrm{kg}{ }^{-1}$ ) through the summer. This does not happen in HNLC areas. The in-situ nutrient data are also consistent with the pattern seen in satellite $[\mathrm{chl}-a]$. Nitrate utilization is more rapid in shallow seas (Table 2). Although there is some seasonal drawdown of nitrate in the deep HNLC areas such as the east and west subarctic North Pacific, the rate of drawdown is not sufficient to exhaust nitrate by the end of the summer (Figure 2). Nutrients are depleted much more rapidly over shelf areas such as the eastern Bering Sea, leading in most cases to nutrient exhaustion over summer (Figure 2). Exceptions 
Table 3. In Situ Measurements Confirming Very High Chlorophyll $a$ Concentrations Over and Near to Shelves ${ }^{\mathrm{a}}$

\begin{tabular}{|c|c|c|}
\hline Area & $\begin{array}{l}\text { Maximum Chlorophyll } a \\
\text { Concentration, } \mathrm{mg} \mathrm{m}^{-3}\end{array}$ & Reference \\
\hline Eastern Bering Sea & 20 & Whitledge et al. [1986]; Figure $2 \mathrm{~g}$ \\
\hline Shelf south of Alaska & 21 & Childers et al. [2005]; Figure 2i \\
\hline British Columbia shelf & 8 & F. A. Whitney, unpublished data \\
\hline Galapagos Islands & 13 & Martin et al. [1994] \\
\hline Ross Sea Shelf & 15 & Smith et al. [2000] \\
\hline $\begin{array}{l}\text { Anvers Island, west of } \\
\text { the Antarctic Peninsula }\end{array}$ & 30 & Holm-Hansen et al. [1989] \\
\hline $\begin{array}{l}\text { Gerlache Strait, west of } \\
\text { the Antarctic Peninsula }\end{array}$ & 25 & Holm-Hansen and Mitchell [1991] \\
\hline $\begin{array}{l}\text { King George Island, north of } \\
\text { the Antarctic Peninsula }\end{array}$ & 19 & Heywood and Priddle [1987] \\
\hline $\begin{array}{l}\text { Bransfield Strait, north of } \\
\text { the Antarctic Peninsula }\end{array}$ & 14 & von Bodungen [1986] \\
\hline Signy Island (South Orkneys) ${ }^{\mathrm{b}}$ & 39 & Clarke and Leakey [1996] \\
\hline South Georgia & 22 & Korb et al. [2004] \\
\hline Bouvet and South Sandwich Islands & 7 & Perissinotto et al. [1992] \\
\hline Kerguelen & 17 & $\begin{array}{l}\text { N. Metzl unpublished data; } \\
\text { auxiliary material supplfig02 }\end{array}$ \\
\hline Crozet & 4 & N. Metzl unpublished data; supplfig02 \\
\hline Prydz Bay, East Antarctica & 23 & Gibson and Trull [1999] \\
\hline
\end{tabular}

${ }^{\mathrm{a}}$ By comparison, in situ measurements in deep HNLC waters average about $0.5 \mathrm{mg} \mathrm{m}^{-3}$ and rarely exceed $1.0 \mathrm{mg} \mathrm{m}^{-3}$ (Figure 2)

${ }^{\mathrm{b}}$ Data are from sampling every week over 6 years.

occur, however, in locations where there is a continuous influx of nutrients throughout the year, such as: (1) the Anadyr Stream, which flows from the deep basin onto the northern part of the Bering Sea shelf [Springer and McRoy, 1993], and (2) the coast of British Columbia during the upwelling season in non-El Niño years [Whitney and Welch, 2002]. Despite a lack of nutrient exhaustion, these waters are also not HNLC; in the Anadyr Stream, high concentrations of phytoplankton persist during a summer-long eutrophic bloom, but do not exhaust the nutrients because of ongoing resupply [Springer and McRoy, 1993]. In both these cases, high nutrients co-exist with high [chl- $a$ ] [Springer and McRoy, 1993; Whitney and Welch, 2002]. In summary, the on-shelf/off-shelf difference seen in satellite [chl- $a$ ] data is corroborated by in situ chlorophyll $a$ and nitrate data.

\subsection{Contribution to Understanding of the HNLC Phenomenon}

[22] How does this pattern relate to the various hypotheses as to the cause of the HNLC phenomenon? Three hypotheses were listed in the introduction: top-down (grazing) control, light limitation and iron limitation.

[23] The on-shelf/off-shelf dichotomy in bloom tendency is not obviously explicable in terms of a grazing (top-down) hypothesis. It has previously been suggested that deep winter mixing (to $\sim 500 \mathrm{~m}$ ) in the North Atlantic (not an HNLC region) makes winter phytoplankton concentrations so dilute that zooplankton starve in winter and are not able to cap the spring blooms, whereas shallow winter mixed layers $(\sim 100 \mathrm{~m})$ at Ocean Weather Station Papa (OWSP) allow overwintering zooplankton to keep a lid on phytoplankton in spring [Fasham, 1995]. It seems hard to reconcile this hypothesis with the picture revealed here of spring phytoplankton blooms in shallow waters, where winter mixing necessarily cannot be deep.

[24] Mixed layers tend to be shallower in coastal waters and in the lee of islands [Mitchell and Holm-Hansen, 1991b], consistent with alleviation of light limitation causing the pattern shown here. However, phytoplankton proliferation occurred universally in response to all Southern Ocean iron enrichments [Martin et al., 1994; Coale et al., 1996; Boyd et al., 2000; Gervais et al., 2002; Tsuda et al., 2003; Coale et al., 2004; Boyd et al., 2004], whatever the mixed layer depth; this would seem to argue for iron scarcity as the overriding limitation, even though the rate of increase in [chl- $a$ ] is found to be negatively correlated with mixed layer depth [de Baar et al., 2005], suggesting that underwater light climate is also an important influence on the development of blooms. Moreover, a light-limitation hypothesis cannot explain the HNLC phenomenon in the subarctic North Pacific, where mixed layer depths are rather shallow year-round $(15-30 \mathrm{~m}$ in summer, maximum $\sim 120 \mathrm{~m}$ in winter), or in the equatorial eastern Pacific Ocean, where mixed layer depths are even shallower.

[25] This pattern of shallow water blooms is consistent with iron scarcity as the cause of HNLC. Many studies concur in finding elevated concentrations of dissolved iron in shallow waters (Table 4). This association between shallow seafloor and higher iron could be due to one or more of several processes, including: iron-rich run-off from land, induced upwelling of iron-rich deep water, and release of iron from the seafloor. However, following Bucciarelli et al. [2001], Johnson et al. [1999], Elrod et al. [2004] and Croot and Hunter [1998], we assume that the sediments are an intense source of iron and therefore that most shallow waters are iron replete. Although most studies have found elevated concentrations of dissolved iron over shelves, Hutchins and Bruland [1998] found phytoplankton to be iron-limited in those parts of the California coastal upwelling region where the continental shelf is particularly narrow, suggesting an exception to shelf blooms (release from iron limitation) in those few regions where both: (1) upwelling is intense, and (2) the shelf is narrow. 
Table 4. In Situ Evidence of Elevated Dissolved Iron Concentrations in Surface Waters Overlying Shallow Topography ${ }^{\mathrm{a}}$

\begin{tabular}{|c|c|c|c|}
\hline Area & Iron Off Shelf, nM & Iron On Shelf, nM & Reference \\
\hline California Current System ${ }^{\mathrm{b}}$ & 0.2 & average 6 , up to 20 & Johnson et al. [1999] \\
\hline Transect from central California to Hawaii ${ }^{\mathrm{b}}$ & 0.2 & $0.8-1.4$ & Elrod et al. [2004] \\
\hline Northwest Atlantic ${ }^{c}$ & $\leq 1.0$ & $0.5-6.0^{\mathrm{d}}$ & Wu and Luther [1996] \\
\hline Northeast Atlantic ${ }^{c}$ & 0.7 & $1-2$ & Boye et al. [2003] \\
\hline $\begin{array}{l}\text { Eastern tropical Pacific, up-stream and } \\
\text { between Galapagos }{ }^{\text {b }}\end{array}$ & 0.06 & 3 & Martin et al. [1994] \\
\hline Kerguelen archipelago and vicinity ${ }^{\mathrm{e}}$ & $0.46-0.71^{\mathrm{f}}$ & $5.3-12.6$ & Bucciarelli et al. [2001] \\
\hline Gulf of Alaska onto shelf south of Alaska ${ }^{e}$ & 0.1 & $0.1^{\mathrm{g}}$ & Martin et al. [1989] \\
\hline Ross $\mathrm{Sea}^{\mathrm{e}}$ & $\leq 0.10$ & 0.22 & Fitzwater et al. [2000] \\
\hline Drake Passage/Gerlache Strait ${ }^{\mathrm{e}}$ & 0.16 & 7.4 & Martin [1990b] \\
\hline
\end{tabular}

${ }^{a}$ Although the large majority of shelf waters appear to be Fe-replete, exceptions in regions of upwelling have been noted [Hutchins et al., 1998; Hutchins and Bruland, 1998].

b"Dissolvable" Fe fraction was measured, determined in unfiltered sampling following a period of acidification. It includes $\mathrm{Fe}(\mathrm{II}+\mathrm{III})$ in the dissolved, colloidal and labile particulate phases.

"Dissolved" Fe fraction was measured, following filtration using $0.2-\mu \mathrm{m}$ pore size filters. It includes Fe(II+III) in the dissolved and possibly colloidal phases.

${ }^{\mathrm{d}}$ Sampling was conducted close to the mouth of the Delaware River. Stations most affected (lowest salinities) were excluded.

e"Dissolved" Fe fraction was measured, following filtration using $0.4-\mu \mathrm{m}$ pore size filters. It includes Fe(II+III) in the dissolved and possibly colloidal phases.

${ }^{\mathrm{f}}$ These offshore values are higher than elsewhere in the open Southern Ocean and are thought to be affected by advection from the continental shelf.

${ }^{\mathrm{g}}$ Measured subsurface (e.g., about $\left.200 \mathrm{~m}\right)$ concentrations were much greater near the shelf $(1-2 \mathrm{nM})$ than offshore $(0.2 \mathrm{nM})$.

[26] While blooms in shallow waters bordering HNLC regions are easily reconciled with the iron limitation hypothesis, it is also possible to conceive of alternative explanations. For instance, the life cycles of some diatom species involve resting spores which sink out of the surface, and the timing and strength of spring blooms could potentially be influenced by the presence or absence of shallow sediments acting as a source of spores [Eilertsen et al., 1995]. Other putative explanations might involve an effect of seafloor depth on zooplankton life cycles. The on-shelf/ off-shelf difference in bloom propensity is fully compatible with lifting of iron limitation due to a seafloor source, but clearly does not constitute proof that iron limitation is the cause of the HNLC phenomenon. The supposition that the distribution of phytoplankton is driven by that of iron can be tested by more detailed studies of iron, phytoplankton and macro-nutrients dynamics where HNLC water meets shallow sediments, and the results of recent studies around the Crozet (CROZEX project) and Kerguelen (KEOPS project) islands are therefore awaited with interest.

\subsection{Cause of High Productivity in the} Eastern Bering Sea

[27] We consider the Bering Sea to be an interesting natural laboratory demonstrating the difference that iron from shallow sediments makes to the HNLC condition. The Bering Sea is split up into a deep western basin (HNLC) and a shallow eastern side consisting of an extensive continental shelf (not HNLC) (Figures 1 and 2). Nitrate is drawn down to limiting concentrations in summer (Figure 2) by spring blooms which remove 15 or more $\mu \mathrm{mol} \mathrm{NO} \mathrm{kg}^{-1}$ [Whitledge et al., 1986; Whitledge and Luchin, 1999; Merico et al., 2005]. The bulk of this nitrate must be exported to below the surface mixed layer and/or to the sediments (there are low stocks in summertime of phytoplankton (Figure 2) and ammonium [Whitledge and Luchin, 1999]).

[28] The eastern Bering Sea is exceptionally productive and supplies over half of the United States demand for fish and shellfish [Macklin, 1999]. It supports populations of king crabs, salmon, and the world's largest single-species fishery: the walleye pollock Theregra chalcogramma [Napp and Hunt, 2001]. The region is also a feeding ground for many resident and migratory seabird and mammal species [Springer et al., 1996]. The data shown here are compatible with the "Iron Curtain" hypothesis [McRoy et al., 2001], which suggests that this high productivity is due in large part to the position of the eastern Bering Sea as an iron oasis adjoining an iron desert. When iron-poor, nitrate-rich waters of the western Bering Sea are supplied with iron as they flow onto the shelf, then phytoplankton proliferation becomes freed from all nutrient limitations. This hypothesis could be tested in future by integrated studies of iron and macronutrient cycling in the North Pacific margins, including across the Bering Sea shelf break.

\subsection{Effects of Ice Ages and Global Warming on High-Latitude Shallow Seas}

[29] This shelf effect also has implications for our understanding of past and future ocean biogeochemistry. For instance, our analysis implies that the subarctic North Pacific HNLC area may have had higher macronutrient concentrations and may have covered a much larger area during glacial times, because the eastern Bering Sea was then a land bridge between Alaska and Siberia rather than, as at present, an enormous hot spot for nutrient removal from seawater (Figures $2 \mathrm{~g}$ and $2 \mathrm{~h}$ ). We speculate that the absence in glacial times of such a large sink for macronutrients may have forced an expansion of the HNLC area to lower latitudes in the North Pacific.

[30] Much of the continental shelf around Antarctica is presently covered by ice year round and is thereby rendered biologically quiescent. Where the shelf is presently ice-free in summer, large blooms occur, for instance in the Ross Sea [Smith et al., 2000], the Weddell Sea (Figure 1) and in Prydz Bay [Gibson and Trull, 1999]. The data reviewed here suggest that the seas around Antarctica could become an increasingly large sink for $\mathrm{CO}_{2}$ as global warming melts back this ice and releases intense biological and biogeo- 
chemical activity around the continent. The iron limitation that experiments suggest is prevalent in the surrounding Southern Ocean appears not to apply near to the continent, and hence incipient phytoplankton blooms are unlikely to be held back by iron limitation. This shelf iron fertilization effect is not included in most existing models; addition of this effect would probably reverse the current model predictions of reduced chlorophyll close to Antarctica under global warming [Sarmiento et al., 2004].

[31] The Arctic Ocean is on average shallower than other oceans, and a third or more of its area consists of continental shelf. The annual extent of sea ice is decreasing significantly under global warming [http://earthobservatory.nasa.gov/ Study/ArcticIce]. As sea ice continues to diminish, this work suggests that phytoplankton blooms will occur in the Arctic Ocean, or at least that potential blooms are unlikely to be prevented by lack of iron [Moore et al., 2004].

[32] The contribution of the sedimentary iron source to total global primary production (TPP) may well be relatively small, however. This has been estimated for the first time by Moore et al. [2004] in a model which includes iron cycling, macronutrient cycling and phytoplankton in a $100 \times 116 \times$ 25 grid cell physical framework. Moore et al. [2004] estimated a minor $(<1 \%)$ effect of sedimentary iron on global TPP, by comparing runs in which their seafloor iron source is switched on to those in which it is switched off. There are significant uncertainties associated with any such estimate, however, related to paucity of our current understanding of iron chemistry and the bioavailability of different iron fractions. In addition, their number may be an underestimate due to setting iron scavenging too high, preventing the influence of seafloor iron spreading away from the shelves. In reality currents and eddies transport iron away from the shelves [Blain et al., 2001; Johnson et $a l ., 2005$ ] and lead to plumes of high chlorophyll $a$ concentration downstream of islands and shelves in the Southern Ocean and elsewhere (section 3). For instance, there is some evidence to suggest that the shelves of South Georgia and the North Scotia Ridge may be responsible for elevated iron [de Baar et al., 1995] and chlorophyll concentrations as much as $2000 \mathrm{~km}$ or more downstream [Korb et al., 2004]. The greater the persistence of sedimentderived iron in the water column, the more its influence will be felt over an area much larger than that of just the shelves themselves, an effect which appears to be underestimated in Moore et al.'s [2004] model. For instance, the model produces low chlorophyll $a$ concentrations in the eastern Bering Sea downstream of Kerguelen, in contrast to observations (Figure 1, auxiliary material supplfig01). A further difficulty inherent in even such high-resolution models is that of accurately representing effects of islands and shelves when they may be smaller than the size of an individual grid box. Moore et al. [2004] may well be correct that it is a relatively small effect, but, given the possible shortcomings of the model, we suggest that more work remains to be done in calculating the quantitative significance to global TPP of fertilization by shelf-derived iron.

\section{Conclusions}

[33] The question addressed in this study was whether HNLC conditions (1) extend into and are unaffected by shallow waters or (2) are alleviated there. This question was tested using a combination of satellite [chl- $a$ ] data and in situ $\left[\mathrm{NO}_{3}\right]$ and $[\mathrm{chl}-a]$ data. We analyzed data from all three HNLC areas but with a focus on the North Pacific. Peak chlorophyll $a$ concentrations were seen to be higher over the shelves. Summer nitrate levels were found to be generally lower (and limiting to phytoplankton growth) over the shelves. The data indicate that HNLC conditions are usually alleviated above shallow seafloor. The on-shelf/off-shelf difference is most notable in the dichotomies between the subarctic NE Pacific and the shelf south of Alaska, and between the deep western and the shallow eastern Bering Sea.

[34] HNLC waters are important globally (accounting for $\sim 30 \%$ of total ocean area) and offer a contrast to the more typical phytoplankton-nutrient dynamics that operate elsewhere. Our data reveal an interesting feature of the natural dynamics: that a shallow seafloor appears to be antagonistic to the HNLC condition. The seafloor is a known source of dissolved iron and so this is consistent with scarcity of iron as the overriding cause of the HNLC phenomenon. According to this understanding, global warming-induced melt-back of ice in coastal or shallow polar regions will probably stimulate increased phytoplankton production and carbon dioxide drawdown, even though these regions generally receive low atmospheric dust inputs.

[35] Acknowledgments. We gratefully acknowledge Matt Pinkerton, Eric Achterberg, Steve Groom, Norman Kuring, and Gavin Tilstone for helpful discussions and reprints, Paolo Cippolini for assistance with digital data sets, and Karl Banse and an anonymous reviewer for thoughtful reviews. T. T. has benefited from NERC and SOC fellowships. Use of OCEANMAP is courtesy of Ralf Prien at the Institut Für Ostseeforschung Warnemünde. The OISO cruises onboard the R.S.S. Marion-Dufresne were supported by three institutes in France (IPEV, INSU, and IPSL/UPMC). We thank Y. Nojiri of the National Institute of Environmental Study, Japan, for collaboration in the sub-arctic ship-of-opportunity program between Vancouver and Japan. SeaWiFS images were provided by the SeaWiFS Project, NASA/Goddard Space Flight Center and ORBIMAGE.

\section{References}

Banse, K. (1996), Low seasonality of low concentrations of surface chlorophyll in the Subantarctic water ring: Irradiance, iron, or grazing?, Prog. Oceanogr., 37, 241-291.

Banse, K. (2002), Steemann Nielsen and the zooplankton, Hydrobiologia, 480, 15-28.

Banse, K., and D. C. English (1999), Comparing phytoplankton seasonality in the eastern and western subarctic Pacific and the western Bering Sea, Prog. Oceanogr., 43, 235-288.

Berner, R. A. (1992), Comments on the role of marine sediment burial as a repository for atmospheric $\mathrm{CO}_{2}$, Global Biogeochem. Cycles, 6, 1-2.

Blain, S., et al. (2001), A biogeochemical study of the island mass effect in the context of the iron hypothesis: Kerguelen Islands, Southern Ocean, Deep Sea Res., Part I, 48, 163-187.

Boyd, P. B., C. S. Wong, J. Merrill, F. Whitney, J. Snow, P. J. Harrison, and J. Gower (1998), Atmospheric iron supply and enhanced vertical carbon flux in the NE subarctic Pacific: Is there a connection?, Global Biogeochem. Cycles, 12, 429-441

Boyd, P. W., et al. (2000), A mesoscale phytoplankton bloom in the polar Southern Ocean stimulated by iron fertilization, Nature, 407, 695-702.

Boyd, P. W., et al. (2004), The decline and fate of an iron-induced subarctic phytoplankton bloom, Nature, 428, 549-553.

Boye, M., A. P. Aldrich, C. M. G. van den Berg, J. T. M. de Jong, M. Veldhuis, and H. J. W. de Baar (2003), Horizontal gradient of the chemical speciation of iron in surface waters of the northeast Atlantic Ocean, Mar. Chem., 80, 129-143.

Bucciarelli, E., S. Blain, and P. Treguer (2001), Iron and manganese in the wake of the Kerguelen Islands (Southern Ocean), Mar. Chem., 73, 21 - 36.

Chavez, F., K. R. Buck, K. H. Coale, J. H. Martin, G. R. DiTullio, N. Welschmeyer, A. C. Jacobson, and R. Barber (1991), Growth rates, grazing, sinking, and iron limitation of equatorial Pacific phytoplankton, Limnol. Oceanogr., 36, 1816-1833. 
Childers, A. R., T. E. Whitledge, and D. A. Stockwell (2005), Seasonal and interannual variability in the distribution of nutrients and chlorophyll $a$ across the Gulf of Alaska shelf: 1998-2000, Deep Sea Res., Part II, 52, $193-216$.

Clarke, A., and R. J. G. Leakey (1996), The seasonal cycle of phytoplankton, macronutrients, and the microbial community in a nearshore Antarctic marine ecosystem, Limnol. Oceanogr., 41, 1281-1294.

Claustre, H., and S. Maritorena (2003), The many shades of ocean blue, Science, 302, 1514-1515.

Coale, K. H., et al. (1996), A massive phytoplankton bloom induced by an ecosystem-scale iron fertilization experiment in the equatorial Pacific Ocean, Nature, 383, 495-501.

Coale, K. H., et al. (2004), et al Southern ocean iron enrichment experiment: Carbon cycling in high- and low-Si waters, Science, 304, 408414.

Comiso, J. C., C. R. McClain, C. W. Sullivan, J. P. Ryan, and C. L. Leonard (1993), Coastal Zone Color Scanner pigment concentrations in the Southern Ocean and relationships to geophysical surface features, J. Geophys. Res., 98(C2), 2419-2451.

Crawford, W. R., P. J. Brickley, T. D. Peterson, and A. C. Thomas (2005), Impact of Haida eddies on chlorophyll distribution in the eastern Gulf of Alaska, Deep Sea Res., Part II, 52, 975-989.

Croot, P. L., and K. A. Hunter (1998), Trace metal distributions across the continental shelf near Otago Peninsula, New Zealand, Mar. Chem., 62, $185-201$

Cullen, J. J., M. R. Lewis, C. O. Davis, and R. T. Barber (1992), Photosynthetic characteristics and estimated growth rates indicate grazing is the proximate control of primary production in the equatorial Pacific, J. Geophys. Res., 97(C1), 639-654.

Darecki, M., and D. Stramski (2004), An evaluation of MODIS and SeaWiFS bio-optical algorithms in the Baltic Sea, Remote Sens. Environ. $89,326-350$

de Baar, H. J. W., and J. T. M. de Jong (2001), Distributions, sources and sinks of iron in seawater, in The Biogeochemistry of Iron in Seawater, edited by D. R. Turner and K. A. Hunter, pp. 123-253, John Wiley, Hoboken, N. J.

de Baar, H., J. T. M. de Jong, D. C. E. Bakker, B. M. Loscher, C. Veth U. Bathmann, and V. Smetacek (1995), Importance of iron for plankton blooms and carbon dioxide drawdown in the Southern Ocean, Nature, $373,412-415$.

de Baar, H., et al. (2005), Synthesis of eight iron fertilization experiments: From the Iron Age in the Age of Enlightenment, J. Geophys. Res., 110, C09S16, doi:10.1029/2004JC002601.

Eilertsen, H. C., S. Sandberg, and H. Tollefsen (1995), Photoperiodic control of diatom spore growth: A theory to explain the onset of phytoplankton blooms, Mar. Ecol. Prog. Ser., 116, 303-307.

Elrod, V. A., W. M. Berelson, K. H. Coale, and K. S. Johnson (2004), The flux of iron from continental shelf sediments: A missing source for global budgets, Geophys. Res. Lett., 31, L12307, doi:10.1029/2004GL020216.

Eplee, R. E., W. D. Robinson, S. W. Bailey, D. K. Clark, P. J. Werdell, M. H Wang, R. A. Barnes, and C. R. McClain (2001), Calibration of SeaWiFS: II. Vicarious techniques, Appl. Opt., 40(36), 6701-6718.

Fasham, M. J. R. (1995), Variations in the seasonal cycle of biological production in sub-arctic oceans-A model sensitivity analysis, Deep Sea Res., Part I, 42, 1111-1149.

Fitzwater, S. E., K. S. Johnson, R. M. Gordon, K. H. Coale, and W. O Smith Jr. (2000), Trace metal concentrations in the Ross Sea and their relationship with nutrients and phytoplankton growth, Deep Sea Res., Part II, 47, 3159-3179.

Frost, B. W. (1991), The role of grazing in nutrient-rich areas of the open sea, Limnol. Oceanogr., 36, 1616-1630.

Gervais, F., U. Riebesell, and M. Y. Gorbunov (2002), Changes in primary productivity and chlorophyll a in response to iron fertilization in the Southern Polar Frontal Zone, Limnol. Oceanogr., 47, 1324-1335.

Gibson, J. A. E., and T. W. Trull (1999), Annual cycle of $\mathrm{fCO}_{2}$ under seaice and in open water in Prydz Bay, East Antarctica, Mar. Chem., 66, $187-200$

Gohin, F., J. N. Druon, and L. Lampert (2002), A five channel chlorophyll concentration algorithm applied to SeaWiFS data processed by SeaDAS in coastal waters, Int. J. Remote Sens., 23, 1639-1661.

Heywood, R. B., and J. Priddle (1987), Retention of phytoplankton by an eddy, Cont. Shelf Res., 7, 937-955.

Holm-Hansen, O., and B. G. Mitchell (1991), Spatial and temporal distribution of phytoplankton and primary production in the Western Bransfield Strait region, Deep Sea Res. Part A, 38, 961-980.

Holm-Hansen, O., B. G. Mitchell, C. D. Hewes, and D. M. Karl (1989), Phytoplankton blooms in the vicinity of Palmer Station, Antarctica, Polar Biol., 10, 49-57.

Hutchins, D. A., and K. W. Bruland (1998), Iron-limited growth and Si:N uptake ratios in a coastal upwelling regime, Nature, 393, 561-564.
Hutchins, D. A., G. R. DiTullio, Y. Zhang, and K. W. Bruland (1998), An iron limitation mosaic in the Californian upwelling regime, Limnol. Oceanogr., 43, 1037-1054

Johnson, K. S., F. P. Chavez, and G. E. Friederich (1999), Continental-shelf sediment as a primary source of iron for coastal phytoplankton, Nature, $398,697-700$.

Johnson, W. K., L. A. Miller, N. E. Sutherland, and C. S. Wong (2005), Iron transport by mesoscale Haia eddies in the Gulf of Alaska, Deep Sea Res., Part II, 52, 933-953.

Korb, R. E., M. J. Whitehouse, and P. Ward (2004), SeaWiFS in the southern ocean: Spatial and temporal variability in phytoplankton biomass around South Georgia, Deep Sea Res., Part II, 51, 99-116.

Landry, M. R., J. D. Kirshtein, and J. R. Constantinou (1995), A refined dilution technique for measuring the community grazing impact of microzooplankton, with experimental tests in the central equatorial Pacific, Mar. Ecol. Prog. Ser, 120, 53-63.

Levitus, S., M. E. Conkright, J. L. Reid, R. G. Najjar, and A. Mantyla (1993), Distribution of nitrate, phosphate and silicate in the world oceans, Prog. Oceanogr., 31, 245-273.

Macklin, S. A. (1999), Report on the FOCI International Workshop on recent conditions in the Bering Sea, NOAA ERL special report, 47 pp., Pac. Mar. Environ. Lab., Seattle, Wash.

Martin, J. H. (1990a), Glacial-interglacial $\mathrm{CO}_{2}$ change: the iron hypothesis, Paleoceanography, 5, 1-13.

Martin, J. H. (1990b), Iron in Antarctic waters, Nature, 345, 156-158.

Martin, J. H., R. M. Gordon, S. E. Fitzwater, and W. W. Broenkow (1989), VERTEX: Phytoplankton/iron studies in the Gulf of Alaska, Deep Sea Res. 36, 649-680.

Martin, J. H., et al. (1994), Testing the iron hypothesis in ecosystems of the equatorial Pacific Ocean, Nature, 371, 123-129.

McRoy, C., T. E. Whitledge, A. M. Springer, and E. P. Simpson (2001), The nitrate front in the Bering Sea: Is this an iron curtain?, paper presented at Aquatic Sciences Meeting, Am. Soc. of Limnol. and Oceanogr., Albuquerque, N. M.

Merico, A., T. Tyrrell, E. J. Lessard, T. Oguz, P. J. Stabeno, S. I. Zeeman, and T. E. Whitledge (2005), Modelling phytoplankton succession on the Bering Sea shelf: Role of climate influences and trophic interactions in generating Emiliania huxleyi blooms 1997-2000, Deep Sea Res., Part I, $51,1803-1826$

Mitchell, B. G., and O. Holm-Hansen (1991a), Biooptical properties of Antarctic Peninsula waters-Differentiation from temperate ocean models, Deep Sea Res., Part A, 38, 1009-1028.

Mitchell, B. G., and O. Holm-Hansen (1991b), Observations and modeling of the Antarctic phytoplankton crop in relation to mixing depth, Deep Sea Res., Part A, 38, 981-1007.

Moore, J. K., and M. R. Abbott (2000), Phytoplankton chlorophyll distributions and primary production in the Southern Ocean, J. Geophys. Res., 105(C12), 28,709-28,722.

Moore, J. K., and M. R. Abbott (2002), Surface chlorophyll concentrations in relation to the Antarctic Polar Front: Seasonal and spatial patterns from satellite observations, J. Mar. Syst., 37, 69-86.

Moore, J. K., S. C. Doney, and K. Lindsay (2004), Upper ocean ecosystem dynamics and iron cycling in a global three-dimensional model, Global Biogeochem. Cycles, 18, GB4028, doi:10.1029/2004GB002220.

Mueller, J. L., et al. (2002), Ocean optics protocols for satellite ocean colour sensor validation, revision 3, in NASA Tech. Memo., 2002-210004, 180 pp.

Muller-Karger, F. E., R. Varela, R. Thunell, R. Luerssen, C. Hu, and J. J. Walsh (2005), The importance of continental margins in the global carbon cycle, Geophys. Res. Lett., 32, L01602, doi:10.1029/2004GL021346.

Napp, J. M., and G. L. Hunt (2001), Anomalous conditions in the southeastern Bering Sea 1997: Linkages among climate, weather, ocean, and Biology, Fish. Oceanogr., 10, 61-68.

O'Reilly, J. E., et al. (2000), Ocean color chlorophyll algorithms for SeaWiFs, OC2 and OC4, NASA Tech. Memo., 2000-206892, 9-27.

Palacios, D. M. (2002), Factors influencing the island-mass effect of the Galapagos Archipelago, Geophys. Res. Lett., 29(23), 2134, doi:10.1029/ 2002GL016232.

Perissinotto, R., R. K. Laubscher, and C. D. McQuaid (1992), Marine productivity enhancement around Bouvet and the South Sandwich Islands (Southern Ocean), Mar. Ecol. Prog. Ser., 88, 41-53.

Peterson, T. D., F. Whitney, and P. J. Harrison (2005), Macronutrient dynamics in an anticyclonic mesoscale eddy in the Gulf of Alaska, Deep Sea Res., Part II, 52, 909-932.

Pinkerton, M. H., K. M. Richardson, P. W. Boyd, M. P. Gall, J. Zeldis, M. D. Oliver, and R. J. Murphy (2005), Intercomparison of ocean colour band-ratio algorithms for chlorophyll concentration in the Subtropical Front east of New Zealand, Remote Sens. Environ., 97, 382-405.

Pollard, R. T., M. I. Lucas, and J. F. Read (2002), Physical controls on biogeochemical zonation in the Southern Ocean, Deep Sea Res., Part II, $49,3289-3305$ 
Press, W. H., S. A. Teukolsky, W. T. Vetterling, and B. P. Flannery (1991), Numerical Recipes in FORTRAN, Cambridge Univ. Press, New York.

Price, N. M., B. A. Ahner, and F. M. M. Morel (1994), The equatorial Pacific Ocean: Grazer-controlled phytoplankton populations in an ironlimited ecosystem, Limnol. Oceanogr., 39, 520-534.

Richardson, K. M., M. H. Pinkerton, P. W. Boyd, M. P. Gall, J. Zeldis, M. D. Oliver, and R. J. Murphy (2004), Validation of SeaWiFS data from around New Zealand, in Climate Change Processes in the Stratosphere, Earth-Atmosphere-Ocean Systems, and Oceanographic Processes from Satellite Data, pp. 1160-1167, Phys. New Books, Quebec.

Sarmiento, J. L., et al. (2004), Response of ocean ecosystems to climate warming, Global Biogeochem. Cycles, 18, GB3003, doi:10.1029/ $2003 \mathrm{~GB} 002134$.

Smith, W. H. F., and D. T. Sandwell (1997), Global seafloor topography from satellite altimetry and ship depth soundings, Science, 277, 19561962.

Smith, W. O., Jr., J. Marra, M. R. Hiscock, and R. T. Barber (2000), The seasonal cycle of phytoplankton biomass and primary productivity in the Ross Sea, Antarctica, Deep Sea Res., Part II, 47, 3119-3140.

Springer, A. M., and C. P. McRoy (1993), The paradox of pelagic food webs in the northern Bering Sea: III. Patterns of primary production, Cont. Shelf Res., 13, 575-599.

Springer, A. M., C. P. McRoy, and M. V. Flint (1996), The Bering Sea Green Belt: Shelf-edge processes and ecosystem production, Fish. Oceanogr., 5, 205-223.

Strom, S. L., M. A. Brainard, J. L. Holmes, and M. B. Olson (2001), Phytoplankton blooms are strongly impacted by microzooplankton grazing in coastal North Pacific waters, Mar. Biol., 138, 355-368.

Sullivan, C. W., K. R. Arrigo, C. R. McClain, J. C. Comiso, and J. Firestone (1993), Distributions of phytoplankton blooms in the Southern Ocean, Science, 262, 1832-1837.

Tsuda, A., et al. (2003), A mesoscale iron enrichment in the western Subarctic Pacific induces a large centric diatom bloom, Science, 300, 958-961.

von Bodungen, B. (1986), Phytoplankton growth and krill grazing during spring in the Bransfield Strait, Antarctica-Implications from sediment trap collections, Polar Biol., 6, 153-160.

Watson, A. J. (2001), Iron limitation in the oceans, in The Biogeochemistry of Iron in Seawater, edited by D. R. Turner and K. A. Hunter, pp. 9-39, John Wiley, Hoboken, N. J.
Whitledge, T. E., and V. A. Luchin (1999), Summary of chemical distributions and dynamics in the Bering Sea, in Dynamics of the Bering Sea, edited by O. K. Loughlin, pp. 217-249, Univ. of Alaska Sea Grant, Fairbanks.

Whitledge, T. E., W. S. Reeburgh, and J. J. Walsh (1986), Seasonal inorganic nitrogen distributions and dynamics in the southeastern Bering Sea, Cont. Shelf Res., 5, 109-132.

Whitney, F. A., and H. J. Freeland (1999), Variability in upper-ocean water properties in the NE Pacific Ocean, Deep Sea Res., Part II, 46, $2351-$ 2370.

Whitney, F., and M. Robert (2002), Structure of Haida eddies and their transport of nutrient from coastal margins into the NE Pacific Ocean, J. Oceanogr., 58, 715-723.

Whitney, F. A., and D. W. Welch (2002), Impact of the 1997-1998 El Niño and 1999 La Niña on nutrient supply in the Gulf of Alaska, Prog. Oceanogr., 54, 405-421.

Whitney, F., W. R. Crawford, and T. Yoshimura (2005), The uptake and export of Si and N in HNLC waters of the NE Pacific, Deep Sea Res., Part II, 52, 1055-1067.

Wong, C. S., N. A. D. Waser, Y. Nojiri, W. K. Johnson, F. A. Whitney, J. S. C. Page, and J. Zeng (2002), Seasonal and interannual variability in the distribution of surface nutrients and dissolved inorganic carbon in the northern North Pacific: Influence of El Niño, J. Oceanogr., 58, $227-243$.

Wu, J., and G. W. Luther (1996), Spatial and temporal distribution of iron in the surface water of the northwestern Atlantic Ocean, Geochim. Cosmochim. Acta, 60, 2729-2741.

A. Merico and T. Tyrrell, National Oceanography Centre Southampton, Southampton University, European Way, Southampton SO14 3ZH, UK. (toby.tyrrell@noc.soton.ac.uk)

N. Metzl, LOCEAN-IPSL, CNRS, Université P et M Curie, Case 134, 4 Place Jussieu F-75252 Paris, France.

J. J. Waniek, Institut Für Ostseeforschung Warnemünde, Seestrasse 15, D-18119 Rostock, Germany.

F. Whitney and C. S. Wong, Institute of Ocean Sciences, P.O. Box 6000 , Sidney, B.C. V8L 4B2, Canada. 